\title{
THE IMPACT OF THE POLLUTION OF THE AQUATIC ENVIRONMENT OF MARINE FISHERIES ON THE FISH PRODUCTION OF SAUDI ARABIA
}

\author{
GHANEM, A. - ALNAFISSA, M.* \\ College of Food and Agriculture Sciences, King Saud University, P. O. Box 2460, Riyadh 11451 \\ Kingdom of Saudi Arabia \\ *Corresponding author \\ e-mail: malnafissa@ksu.edu.sa \\ (Received $18^{\text {th }}$ Apr 2019; accepted $11^{\text {th }}$ Jul 2019)
}

\begin{abstract}
The research aimed to measure the impact of pollution of the aquatic environment of marine fisheries on fish production in Saudi Arabia. This study achieves its objectives based on published secondary data and the estimation of the recursive model by ordinary least squares (OLS) method during the 1995-2017 period. The results of the study show the decline of the productivity of fishing vessels due to overfishing and failure to keep pace with the biological growth rate. The proportion of fish stocks within a biologically sustainable level declined from $87 \%$ in 2013 to $54 \%$ in 2017 . The major factor of the decline of fish stocks and the productivity of fishing vessels is the environmental pollution of marine fisheries such as untreated sewage. The $10 \%$ increase of untreated sewage leads to a decrease in marine fish production by $20.9 \%$.
\end{abstract}

Keywords: productivity, overfishing, wastewater, recursive model, Red Sea, Arabian Gulf

\section{Introduction}

The coast of Saudi Arabia extends over 2,900 km of the Red Sea and Arabian Gulf. The number of fishermen and fishing workers in the Kingdom is around 28.04 thousand, reaching $0.86 \%$ of the total population of 32.55 million in 2017 (Ministry of Environment, Water and Agriculture, 2017). Even with the expansion of the fishing water area and the increase in the number of fishermen and fishing vessels, fish production does not meet the increasing consumption needs. Therefore, there is an increase in the import of fish to the country. The total quantity of fish imports reached 163.85 thousand tons, valued at SR 1315.26 million of the total value of imports of agricultural and animal products which is 27303 million riyals in 2017 (General Authority for Statistics, 2017).

Due to the rapid development of the petrochemical industry in Saudi Arabia, the amount of waste, whether oil, industrial, or carbon ash waste from fuel combustion, in power generation and desalination plants has increased. The Kingdom's solid waste is estimated at about 12 million metric tons annually from the petrochemical, cement and oil refining industries. Heavy materials are thrown into the sea or buried in the soil, desert. Besides the impact of heavy fuel oil waste used in power plants and saltwater desalination on Saudi's marine environment, there is an effect of overfishing of fish stocks in the Red Sea and Arabian Gulf (Alnashwan and Ghanem, 2010). There are several studies have addressed the environmental problems of different fisheries.

Basaham et al. (2009) study showed that although Jeddah's sewage estuary has been moved to the edge of the coral reef towards the open sea, pollution remains widespread, endangering coastal environments and posing a threat to public health. This was evidenced by the heavy growth of algae and the increased concentration of heavy 
elements in sediments. Al-Najjar (2015) estimated some heavy elements in the Chirocentrus dorab fish caught from the Iraqi coast. The results showed the total concentration of elements (lead, iron, nickel, cobalt, and copper) was $6590.26 \mu \mathrm{g} / \mathrm{g}$ dry weight for fish. Bouazem and Wennon (2015) estimated the revenues and costs of seawater desalination for Saudi Arabia during the period 2000-2014. In terms of cost, the cost of energy is one of the depleted natural resources, as well as the environmental costs summarized by the volume of emissions and saline solution from the stations. The cost of pollution from desalination plants, especially $\mathrm{CO}_{2}$, is estimated at $19.4 \$$ per ton.

Qubartai's (2016) study addressed the environmental impact assessment of desalination technology and its relationship to pre-treatment levels. The saline water desalination results in a brine solution that increases salt content in the water. Additive chemicals also increase pollution. The environmental impact of desalination plants depends on both the physic-chemical properties of the discharged water and the hydrographic and biological properties of the aquatic environment. The other study by Alamin and Guthi (2017) dealt with marine environmental pollution through international law. The study showed that the marine environment is part of the global ecosystem. International law guarantees a set of rules for the protection of the marine environment, the obligations of States and measures that States must apply to their domestic legal systems with a view to protecting the marine environment from pollution.

Qamra et al. (2018) studied the economic effects of Lake Mariout pollution on agricultural production during the period 1990-2015. This study shows the increase of the total quantity of industrial and agricultural waste and the drainage of Alexandria Governorate by $10 \%$ leads to a decrease in the production of fish of Mariout Lake by $12.9 \%$. Finally, the Ministry of Environment, Water and Agriculture of the Kingdom of Saudi Arabia (2018) prepared a national strategy for the environment, in view of the increasing pressures on the environment and natural resources in the Kingdom during the past decades. The strategy explained the increasing consumption of non-renewable water and the growing sources of water pollution.

This study aimed to analyze the effect of pollution of the aquatic environment on fish production in Saudi Arabia during the period 1995-2017 by studying the following objectives:

1. The current status of fish production and productivity of vessels operating in Saudi Arabia's marine fisheries.

2. Problems of the aquatic environment of marine fisheries (the Red Sea and the Arabian Gulf).

3. Measuring the impact of pollution of the aquatic environment on the quantity and value of fish production in Saudi Arabia.

\section{Definitions}

Through the study there are several research concepts, the most important of which are the following:

Environmental pollution. Pollution is defined as the state of the environment itself or the resultant changes in it and causes the person a direct or indirect disturbance, damage, disease or death. Pollution is also defined as any quantitative or qualitative change in the components of the living or non-living environment, and environmental systems cannot absorb it without changing its balance. Quantitative change results in the addition of toxic substances that are deadly in their natural concentrations such as 
mercury, carbon oxide, and derived substances, while qualitative variation results from the addition of artificial compounds to natural ecosystems (Alnashwan and Ghanem, 2010).

Modern boats (commercial vessels). Boats with a length of more than nine meters, and contain modern equipment such as the discovery of places of gathering fish, electronic navigation equipment and modern communications devices, in addition to the winch and fishing equipment of high efficiency.

Traditional boats. Boats that are between 5 and 20 meters long and do not contain the equipment included in the modern boats, except for the winch and the bottom trawling of the shrimp fishing in the Arabian Gulf.

Fishermen could be called for traditional fishermen, investors, and fishermen for temporary periods. A traditional fisherman is a citizen who works himself in a fishing craft on a boat he owns. An investor is a citizen who invests part or all of his money in marine fisheries and owns modern fishing boats. The temporary fisherman refers to the children of fishermen who work with their parents in the marine fisheries sector and are under the age of 18 years. In addition, the other citizen fisherman who does the fishing but does not own boats or fishing boats (Ghanem and Al-Obaid, 2002).

\section{Materials and methods}

The study based on the secondary data presented in the statistical yearbook issued by the Ministry of Environment, Water, and Agriculture, in addition to the Bulletin of Export and Import Statistics published by the General Authority for Statistics. The proposed model of this study to analyze the impact of pollution of the aquatic environment on fish production during the period 1995-2017 through Recursive model consists of two behavioral equations (Eq. 1 and 2) and an indicative equation (Eq. 3). These equations are as follows:

$$
\begin{gathered}
Y_{1 t}=a_{0}+a_{1} X_{1 t}+a_{2} X_{2 t}+a_{3} X_{3 t}+e_{1 t} \\
Y_{2 t}=b_{0}+b_{1} \hat{Y}_{1 t}+b_{2} X_{4 t}+e_{2 t} \\
Y_{3 t}=\hat{Y}_{2 t} \times X_{5 t}
\end{gathered}
$$

These equations of the model include the following variables: (1) Endogenous Variables: there are three variables which are the fish production of the Red Sea and Arabian Gulf in thousand tons $\left(\mathrm{Y}_{1 \mathrm{t}}\right)$, the total fish production of Saudi fisheries per thousand tons $\left(\mathrm{Y}_{2 \mathrm{t}}\right)$, and the value of fish production in billion riyals $\left(\mathrm{Y}_{3 \mathrm{t}}\right)$; and (2) Exogenous Variables: there are five variables which are the number of fishing boats $\left(\mathrm{X}_{1 \mathrm{t}}\right)$, number of licensed fishermen $\left(\mathrm{X}_{2 \mathrm{t}}\right)$, total untreated wastewater in million cubic meters $\left(\mathrm{X}_{3 \mathrm{t}}\right)$, the total production of the rest of Saudi fisheries in thousand tons $\left(\mathrm{X}_{4 \mathrm{t}}\right)$, and the average wholesale price of fish by thousand riyals/ton $\left(\mathrm{X}_{5 \mathrm{t}}\right)$. It is clear from the proposed model that the fish production of the Red Sea and Arabian Gulf affects the total fish production of Saudi fisheries and thus affects the value of fish production. Thus, the causality is carried in one direction and not in the other. Models that follow this pattern are called the Recursive Model (Abdelkader, 1990). 


\section{Results}

\section{Current status of fish production and productivity of vessels}

By following the change in fish production and the productivity of vessels operating in Saudi Arabia's marine fisheries during the period 1995-2017 (Table 1), it is clear that most of the vessels engaged in marine fisheries (the Red Sea and Arabian Gulf) are traditional. Fishing vessels are concentrated in the Red Sea, whereas $80.22 \%$ of the total number of vessels is employed, while only $19.78 \%$ in the Arabian Gulf during the study period. Even though the fisheries of Arabian Gulf dominated fish production, with the average production reach to 34.28 thousand tons that represent $45.34 \%$ of the average total fish production, followed by Red Sea fisheries by $31.7 \%$, followed by fish farms and international waters by $22.16 \%$ and $1.07 \%$ respectively.

Table 1. Statistical analysis of the evolution of the number of boats, fishermen, fish production and the production of fishing boats in the Red Sea and Arabian Gulf (19952017). (Source: collected and calculated from Statistical Yearbook, Ministry of Environment, Water and Agriculture, Statistics and Information Department, several editions, 1995-2017)

\begin{tabular}{c|c|c|c|c|c|c}
\hline List & Minimum & Maximum & Average & $\begin{array}{c}\text { Standard } \\
\text { deviation }\end{array}$ & $\begin{array}{c}\text { Coefficient of } \\
\text { variation } \%\end{array}$ \\
\hline \multicolumn{7}{c}{ The number of fishing boats in the Red Sea } \\
\hline Traditional & 5055 & 10102 & 8110 & 1762.71 & 21.74 \\
\hline Modern & 108 & 169 & 150 & 16.91 & 11.31 \\
\hline \multicolumn{7}{c}{ The number of fishing boats in Arabian Gulf } \\
\hline Traditional & 1799 & 3768 & 2012 & 403.56 & 20.06 \\
\hline Modern & 5 & 45 & 26 & 13.57 & 53.10 \\
\hline $\begin{array}{c}\text { Total number of vessels in } \\
\text { marine fisheries }\end{array}$ & 7157 & 12195 & 10297 & 1689.23 & 16.40 \\
\hline \multicolumn{7}{c|}{ Numbers of fishermen and fishing workers } \\
\hline $\begin{array}{c}\text { Fishermen } \\
\text { Saudi fishing workers }\end{array}$ & 1000 & 10270 & 8275 & 2117.6 & 25.59 \\
\hline $\begin{array}{c}\text { Non Saudi fishing workers } \\
\text { and fishing workers }\end{array}$ & 11772 & 17112 & 15111 & 1860.69 & 12.31 \\
\hline
\end{tabular}

Production of vessels operating in the Red Sea in thousand tons

\begin{tabular}{c|c|c|c|c|c}
\hline Traditional & 13.24 & 18.68 & 16.77 & 1.50 & 8.95 \\
\hline Modern & 5.12 & 9.21 & 7.20 & 1.35 & 18.81 \\
\hline Total & 20.45 & 27.51 & 23.97 & 1.98 & 8.27 \\
\hline
\end{tabular}

Production of vessels operating in Arabian Gulf in thousand tons

\begin{tabular}{c|c|c|c|c|c}
\hline Traditional & 18.44 & 45.19 & 33.88 & 8.88 & 26.20 \\
\hline Modern & 0.04 & 2.06 & 0.40 & 0.62 & 153.73 \\
\hline Total & 19.58 & 45.26 & 34.28 & 8.45 & 24.65 \\
\hline $\begin{array}{c}\text { International water production } \\
\text { per thousand tons }\end{array}$ & 0 & 3.91 & 0.81 & 1.33 & 164.55 \\
\hline $\begin{array}{c}\text { Production of fish farms in } \\
\text { thousand tons }\end{array}$ & 2.69 & 55.00 & 16.75 & 13.57 & 80.97 \\
\hline $\begin{array}{c}\text { Total fish production per } \\
\text { thousand tons }\end{array}$ & 48.39 & 121.40 & 75.61 & 20.64 & 27.29 \\
\hline
\end{tabular}




\begin{tabular}{c|c|c|c|c|c}
\hline \multicolumn{6}{c}{ Average productivity of vessels operating in the Red Sea per ton/vessel } \\
\hline Traditional & 1.32 & 3.21 & 2.18 & 0.56 & 25.81 \\
\hline Modern & 32.07 & 64.69 & 48.60 & 9.74 & 20.04 \\
\hline Average productivity of vessels operating in the Arabian Gulf per ton/vessel \\
\hline Traditional & 9.66 & 22.97 & 17.02 & 4.33 & 25.42 \\
\hline Modern & 1.43 & 45.78 & 13.40 & 13.38 & 99.85 \\
\hline
\end{tabular}

The average productivity of traditional vessels in Red Sea fisheries decreased from 2.95 tons/vessel in 1995 to 2.58 tons/vessel in 2017. By taking the same period of time, the productivity of modern vessels in Red Sea fisheries also decreased from 63.79 to 33.18 tons/vessel. The average productivity of modern vessels in Arabian Gulf fisheries decreased from 25.33 to 10.0 tons/vessel during the same period of time.

\section{The impact of pollution of the aquatic environment on the quantity and value of fish production}

To study the economic effects of the pollution of the aquatic environment on quantity and value of Saudi Arabia's fish production, the equations of the proposed model were estimated by the ordinary least squares (OLS) method during the period 1995-2017. The result from a model analysis in Table 2 shows the increase of untreated sewage waste in Saudi Arabia by $10 \%$ leads to a decrease of $20.9 \%$ in fish production of marine fisheries. The increase in the estimated of production of marine fisheries by $10 \%$ leads to an increase in total fish production of Saudi Arabia by $0.8 \%$, while an increase of $10 \%$ for the production of the rest of Saudi fisheries leads to an increase in total fish production by $9.9 \%$. The significance of this estimation is at $1 \%$. According to the Breusch-GodFrey serial correlation LM Test, there is no autocorrelation in the errors in an estimated regression model. Also, there is no autocorrelation in the squared series, according to the Arch Test. In addition, the estimated equations are well represented in the data used in this estimation according to the efficiency indicators of the model such as U Theil's inequality coefficient, which is close to zero (Table 3).

Table 2. An estimated model of the impact of pollution on the quantity and value of fish production of Saudi Arabia (1995-2017). (Source: Computed from Statistical Yearbook, Ministry of Environment, Water and Agriculture, 1995-2017)

\begin{tabular}{|c|c|}
\hline List & Equation \\
\hline $\begin{array}{l}\text { Production of } \\
\text { marine fisheries }\end{array}$ & $\begin{array}{c}\operatorname{Ln} \hat{\mathrm{Y}}_{1}=-16.028+0.06 \operatorname{Ln} X_{1}-0.209 \operatorname{Ln} X_{3}+0.69 A R(1) \\
(-2.22)^{*}(1.96)^{*} \quad(-2.43)^{*} \quad(5.77)^{* 8} \\
R^{2}=0.82 \quad F=31.37 \quad \text { D. } W=1.67 \\
\text { LM test }=0.17 \text { Arch test }=0.06\end{array}$ \\
\hline $\begin{array}{l}\text { Total fish } \\
\text { production }\end{array}$ & $\begin{array}{c}\operatorname{Ln} \hat{\mathrm{Y}}_{2}=0.05+0.008 \operatorname{Ln} \hat{\mathrm{Y}}_{1}+0.099 \operatorname{Ln} X_{4}+0.62 \mathrm{AR}(1) \\
(5.29) \quad(2.07)^{*} \quad(449.77)^{*}(2.80) \\
R^{2}=0.99 F=1859763 \text { D.W }=1.39 \\
\text { LM test }=0.44 \text { Arch test }=0.70\end{array}$ \\
\hline $\begin{array}{c}\text { Total value of fish } \\
\text { production }\end{array}$ & $Y_{3}=\hat{Y}_{2} * X_{2}$ \\
\hline
\end{tabular}

**Statistically significant at level $1 \%$. Statistically significant level $5 \%$ 
Table 3. Indicators for measuring the efficiency of the estimated model (1995-2017). (Source: Compiled and calculated from the behavioral equations of the estimated model in Table 3)

\begin{tabular}{c|c|c}
\hline \multirow{2}{*}{ Indicator } & \multicolumn{2}{|c}{ Behavioral equation } \\
\cline { 2 - 3 } & First & Second \\
\hline The root mean square error (RMSE) & 0.19 & 0.001 \\
Mean absolute error (MAE) & 0.15 & 0.0009 \\
Mean absolute percentage error (MAPE) & 9.40 & 0.01 \\
(U) Theil: Theil inequality coefficient & 0.06 & 0.00008 \\
\hline
\end{tabular}

\section{Discussion}

In general, it is clear the degradation of the productivity of vessels in Saudi fishery marines during the period of study. This could be caused by different factors such as:

- The continuous increase in the number of fishermen and traditional and modern vessels in the Red Sea and Arabian Gulf regions. Whereas increasing the number of boats in a fishing area means increasing the number of fishing trips on the same fishing area. This phenomenon is known as overfishing, which leads to a failure to keep pace with the rate of biological growth of the fish catch rate, and thus to affect the fish stocks of those.

- The ability of most fishing vessels operating in marine fisheries is less than 100 mechanic horses. Therefore, these vessels cannot sail long distances at sea and approach the continental slope. Since there is a direct relationship between the power of the motor or the engine and sailing long distances in Sea, stand the weather conditions is appropriate, and stay longer in the sea.

\section{Problems of the aquatic environment of Saudi marine fisheries}

The marine fisheries of Saudi Arabia have been exposed to several environmental problems, the most important of which is pollution and the phenomenon of overfishing. The pollution of the aquatic environment of Saudi marine fisheries is attributed to several factors: (1) the movement of oil tankers and commercial vessels between East and West, which makes marine fisheries vulnerable to pollution during loading and unloading operations, ship refueling and waste disposal, (2) discharge of untreated sewage and waste of industrial facilities located on the coast of Red Sea and Arabian Gulf, (3) port clearance and ship maintenance and painting, (4) seawater desalination companies, (5) oil and mineral exploration in marine waters, (6) the management of maritime ports and oil companies may have to use chemicals to disperse spots Oily resulting from some accidental accidents and spills, and (7) oil spill resulting from the military operations. Whereas there was an oil spill from Nowruz Field that lasted for eight months during the Iran-Iraq war in 1983. The amount of oil spilled ranged from 200 to 500 thousand tons. Also, the amount of oil leaking was about one million tons during the war of the liberation of Kuwait in 1991. Despite efforts to contain this massive oil spill, it was a major cause of the destruction of at least $300 \mathrm{~km}$ from the eastern coast of Saudi Arabia and the deaths of many marine organisms and birds. Because of the pollution of the aquatic environment of marine fisheries and overfishing, the rate of biological growth of the fishing rate has not kept up with a fishing rate. The 
data in Table 4 show that the percentage of fish stocks within a biologically sustainable level has decreased from $87 \%$ in 2013 to $54 \%$ in 2017.

Therefore, the pollution of the aquatic environment of marine fisheries is one of the main reasons to decrease the rate of biological growth of the fish that leads to a decrease in the percentage of fish stocks within a biologically sustainable level. This reason confirms by the result of data analysis through this study which there is an inverse relationship between untreated sewage waste and fish production of marine fisheries in Saudi Arabia.

Table 4. Evolution of the size and proportion of fish stocks within the biologically sustainable level (2010-2017). (Source: Statistical Yearbook, Ministry of Environment, Water and Agriculture, 2017)

\begin{tabular}{c|c|c}
\hline Year & $\begin{array}{c}\text { Size of fish stocks within the biologically } \\
\text { sustainable level by 1,000 tons }\end{array}$ & $\begin{array}{c}\text { Percentage of fish stocks within a } \\
\text { biologically sustainable level \% }\end{array}$ \\
\hline 2010 & 65.07 & 71 \\
2011 & 63.17 & 79 \\
2012 & 71.39 & 80 \\
2013 & 61.77 & 87 \\
2014 & 67.99 & 74 \\
2015 & 64.88 & 62 \\
2016 & 66.54 & 62 \\
2017 & 66.40 & 54 \\
\hline
\end{tabular}

\section{Conclusion}

Pollution sources of marine fisheries (the Red Sea and Arabian Gulf) are abundant in the territorial waters of Saudi Arabia which have negative impacts on fish production, health, and human well-being. Shows the increase of untreated sewage waste in Saudi Arabia by $10 \%$ leads to a decrease of $20.9 \%$ in fish production of marine fisheries. In order to protect marine fisheries from pollution, the study recommends the following: (1) Raise awareness about the importance of preserving the marine environment through research and regulation of fishing rules such as length of fishhook, number of fishing trips, minimum and maximum size of fish, the amount of fishing, the prohibited fishing seasons and prohibited fishing sites, (2) develop fishing boats and increase their ability to sail long distances in the Red Sea and Arabian Gulf, so the phenomenon of overfishing can be eliminated and the preservation of fish stocks, (3) tighten control over all facilities and plants that discharge their wastes in marine waters, (4) improve the primary treatment of sewage, (5) implement more research to study the effect of pollution to damages the marine natural resources in Saudi Arabia and analysis the effective policy tools to improve aquatic environment, and (6) Cooperation among the Gulf Cooperation Council (GCC) countries on the establishment of a network to monitor and control pollution. This may require aerial and night monitoring and surveillance to detect expected violations.

Acknowledgements. The authors extend their sincere appreciation to the Deanship of Scientific Research at King Saud University for supporting the work through the College of Food and Agricultural Sciences Research Center. Furthermore, the authors thank the Deanship of Scientific Research at King Saud University for their technical support. 


\section{REFERENCES}

[1] Abdelkader, A. (1990): Methods of Measuring Economic Relations with Computer Applications. - Egyptian Universities House, Alexandria.

[2] Alamin, M., Guthi, Q. (2017): Marine environmental pollution in light of international law. - Journal of Scientific Research in International Legislation 5(9): 429-439.

[3] Al-Najjar, G. (2015): The accumulation of some heavy metals in the chiocentrus dorab fish caught from Iraqi coasts. - Journal of King Saud University, Agricultural Sciences 26(2): 127-143.

[4] Alnashwan, O., Ghanem, A. (2010): Environmental Economic Policies and Measurements - Applied Study in Saudi Arabia and Egypt. First Ed. - Al-Moayad Publishing and Distribution House, Saudi Arabia.

[5] Basaham, A., Rifaat, A., El-Mamoney, M., El Sayed, M. (2009): Re-evaluation of the impact of sewage disposal on coastal sediments of the southern Corniche, Jeddah, Saudi Arabia. - Journal of King Abdulaziz University, Marine Sciences 20(1): 109-126.

[6] Bouazem, K., Wennon, A. (2015): Desalination of seawater in Saudi Arabia: realized revenues and costs incurred during the period (2000-2014). - Arab Economic Research Journal 71: 21-42

[7] General Organization for Statistics (2017): Import Statistics. - Riyadh, Saudi Arabia.

[8] Ghanem, A., Al-Obaid, A. (2002): The economic dimension of fish production and consumption in Saudi Arabia. - Journal of King Saud University, Agricultural Sciences 14(2): 191-198.

[9] Ministry of Environment, Water and Agriculture (1995-2017): Statistical Yearbook (several editions). - Statistics and Information Department, Riyadh, Saudi Arabia.

[10] Ministry of Environment, Water and Agriculture (2017): Executive Summary of the National Environmental Strategy. - Riyadh, Saudi Arabia.

[11] Qamra, S., Jamila, A., Hassan, G. (2018): Study of the economic impacts of Lake Mariout pollution on agricultural production. - Egyptian Journal of Agricultural Economics 29(3) September: 110-145.

[12] Qubartai, S. (2016): Environmental impact assessment of desalination technology and its relation to pre-treatment quantities. - Journal of Environmental Research and Sustainable Development 145(1): 145-163. 